\title{
TECHNOLOGICAL CHARACTERIZATION AND CLASSIFICATION OF WHEAT LINEAGES CULTIVATED IN THE CERRADO MINEIRO
}

\author{
Caracterização tecnológica e classificação de linhagens de trigo cultivadas no cerrado mineiro
}

\author{
Raul Antônio Viana Madeira ${ }^{1}$, Anderson Felicori Fernandes², Wagner Pereira Reis ${ }^{3}$, \\ Carlos Wanderlei Piler de Carvalho ${ }^{4}$, Joelma Pereira ${ }^{2}$
}

\begin{abstract}
Farmers need highly productive wheat cultivars in order to reach better profitability. However, this alone is not enough, because, in order to serve the mills, the food industry, and more specifically, the bakers, wheat cultivars must present minimum quality requirements that result in final products of superior quality. This study was conducted with the goals of performing the technological characterization of wheat flour five lineages developed for cultivation in the Cerrado Mineiro; compare the flours of these lineages with the wheat flour of two commercial wheat cultivars, and classify the wheat lineages according to current Brazilian legislation. A completely randomized design was conducted with seven treatments and three replicates. Moisture, protein and ashes content, and the rheological characteristics of the flours were determined. The EP066066 lineage as rated was basic wheat. The EP066055, EP064021, EP062043 and EP063065 were rated as bread wheat. Among the studied lineages, the wheat flour from the EP062043 stood from the others, presenting considerable gluten contents, good level of mixing tolerance, good stability and good gluten strength.
\end{abstract}

Index terms: Wheat flour; quality; alveography; farinography; legislation.

\section{RESUMO}

Para alcançar melhor rentabilidade, o produtor necessita de cultivares de trigo de alta produtividade. Porém, só isso não é suficiente, pois, para atender aos moinhos, à indústria de alimentos e, mais especificamente, aos panificadores, as cultivares de trigo devem apresentar requisitos mínimos de qualidade, para resultar em produtos finais também de qualidade superior. Este trabalho foi conduzido com o objetivo de realizar a caracterização tecnológica da farinha de trigo de cinco linhagens de trigo desenvolvidas para o plantio no Cerrado Mineiro; comparar as farinhas dessas linhagens com a farinha de trigo de duas cultivares de trigo comerciais e a classificar as linhagens de trigo conforme a legislação brasileira vigente. Um delineamento, inteiramente casualizado, foi conduzido com sete tratamentos e três repetições. Foram determinados: a umidade, o conteúdo proteico e de cinzas e as características reológicas das farinhas. A linhagem EP066066 foi classificada como trigo básico. As linhagens EP066055, EP064021, EP062043 e EP063065 foram classificadas como trigo pão. Dentre as linhagens estudadas, a farinha de trigo da EP062043 se destacou das demais, apresentando consideráveis conteúdos de glúten, bom índice de tolerância à mistura, boa estabilidade e boa força de glúten.

Termos para indexação: Farinha de trigo; qualidade; alveografia; farinografia; legislação.

\section{INTRODUCTION}

The Brazilian cerrado is presented as an alternative to the production of wheat grains in rain-fed or irrigated crop. National research institutions have developed wheat that is adapted to the central Brazilian region, which allows elevated grain productivity (Felicio, 1996). Borges et al. (2011) affirm that only the agronomic characteristics are not enough to comply with the market needs.

This way, the elements of flour quality include the amount and the quality of the protein, the moisture, the ashes, the gluten content and strength, the water absorption capacity, the mixing properties, the body elastic and extensible capacity, alpha-amylase content, and the damaged starch content (Germani, 2003). In this context, the genetic enhancement programs face the challenge of obtaining cultivars that better comply with all the sections of the wheat agro-industrial chain (Gutkoski et al., 2007a).

In 2010, the Brazilian Ministry of Agriculture, Livestock and Supply published the Normative Instruction $\mathrm{n}^{\circ} 38$, which establishes the Technical Regulation of Wheat Identity and Quality with five classes improving wheat, bread wheat, home wheat, basic wheat and wheat for other uses, and also in three types (Type 1,2 and 3) (Brazil, 2010).

This normative instruction enabled Brazilian commercial and industrial activities to follow guidelines,

\footnotetext{
${ }^{1}$ Universidade Federal de Lavras/UFLA - Departamento de Ciência dos Alimentos/DCA - Campus Universitário - Cx. P. 3037 - $37200-000$ - Lavras MG - Brasil - raulmadeira@yahoo.com.br

2Universidade Federal de Lavras/UFLA - Departamento de Ciência dos Alimentos/DCA - Lavras - MG - Brasil

3Universidade Federal de Lavras/UFLA - Departamento de Agricultura/DAG - Lavras - MG - Brasil

${ }^{4}$ Empresa Brasileira de Pesquisa Agropecuária/EMBRAPA - Centro Nacional de Pesquisa de Tecnologia Agroindustrial de Alimentos - Rio de Janeiro - RJ - Brasil

Received in august 27, 2014 and approved january 13, 2015
}

Ciênc. Agrotec., Lavras, v.39, n.3, p.283-290, maio/jun., 2015 
and it partly complies with the needs of the milling and final products (bread, dough, cookies fabrication) industries, because it offers a quality index for wheat of different uses (Franco, 2011). This way, basic wheat is indicated to the production of biscuits, cookies and cakes; home wheat is ideal for flour used in homemade preparations; bread wheat is recommended to the fabrication of bread; and the improving wheat is indicated for mixtures or fabrication of pasta products, crackers and some types of bread (Guarienti et al., 2013).

This study was done with the goal of proceeding to the technological characterization of the wheat flours from five wheat lineages originated at the Program for Genetic Improvement of Wheat, by the Agricultural Research Company of Minas Gerais, developed to be cultivated in the cerrado mineiro; comparing with two commercial wheat cultivars and rate them according to current Brazilian legislation.

\section{MATERIAL AND METHODS}

In this experiment the flours obtained from the following wheat lineages were evaluated: EP062043, EP066066, EP066055, EP064021 and EP063065; as well as the wheat flours of two cultivars, CD 108 and BRS 264, commercially rated as bread wheat, according to V Reunião da Comissão Brasileira de Pesquisa de Trigo e Triticale (2011), both cultivated in the cerrado mineiro. The flours were obtained through the milling of the wheat grains at an experimental mill (Brabender Quadrumat Senior, Brabender, Germany). A completely randomized delimitation (CRD) was used, conducted with seven treatments and three replicates.

The moisture was determined through fast method, using infra-red moisture analyzer, (MOC-120H, Shimadzu, Brazil). The computation of mineral matter and of protein content (conversion factor $=5.7$ ) followed the recommendations of the Association of Official Analytical Chemists - AOAC (2000).

The fat acidity was determined after the drying of the samples in a greenhouse (320-SE, Fanem, Brazil), at $40^{\circ} \mathrm{C}$, for 24 hours and screening in sieves with opening of 40 mesh. The result had as basis the fat neutralization, extracted after 16 hours, through the Soxhlet method, with $\mathrm{KOH}(0,0178 \mathrm{~N})(\mathrm{AACC}, 2000)$.

The determination of the color parameters $\mathrm{L}^{*}$ (luminosity); $a^{*}$ (green to red); $b^{*}$ (blue to yellow) and $\Delta \mathrm{L}$ were determined in Konica Minolta (Chroma Meter CM700, Konica Minolta, Brazil) equipment with D65 and SCE illuminant excluded (AACC, 2000).
The gluten percentage determination was proceeded through the Glutomatic System (Glutomatic System, Perten Instruments, Sweden), with determination of gluten index (GI), dry gluten (GS), and humid gluten (GU), based

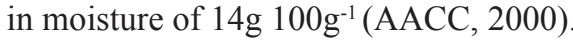

The falling number was obtained through the measurement of capacity of the alpha-amylase enzyme in liquefying the wheat starch gel; time was measured (in seconds) to know how long it would be required for the suspension to allow the fall of the agitator until a fixed distance, under constant temperature of $100{ }^{\circ} \mathrm{C}$, in proper equipment (Falling Number FN1500, Perten Instruments, Sweden) (AACC, 2000).

The gluten quality was evaluated at a Chopin alveograph (Alveograph NG, Chopin, France). The alveographic parameters were: persistence (P), extensibility (L), both in millimeters, and the energy of mass deformation (W), expressed in $0^{-4} \mathrm{~J}$ (AACC, 2000).

The farinographic parameters were obtained in farinographic equipment (Farinographer Brabender Model FA/R-2, Brabender, Germany). In this procedure data about flours capacity of absorbing water (in percentage), stability (in minutes), arrival time (in minutes), fall time (in minutes), departure time (in minutes), 20 minutes of fall in farinographic units (UF), and mixture tolerance index (ITM) (AACC, 2000) were obtained.

The results found for the proximate composition, fat acidity, color, gluten, falling number, elasticity, extensibility and $\mathrm{P} / \mathrm{L}$ relation were submitted to analysis of variance (ANOVA), and the treatments that presented differences were identified by the Tukey test $(\mathrm{p}<0.05)$. The class of the studied wheat was determined based on the Appendix III of the Normative Instruction $n^{\circ} 38$, by the Brazilian Ministry of Agriculture, Livestock and Supply (Brazil, 2010).

\section{RESULTS AND DISCUSSIONS}

The chemical composition of the wheat flours obtained through wheat grain experimental milling is presented on Table 1. According to the Normative Instruction $\mathrm{n}^{\mathrm{o}} 38$, which defines the identity and quality characteristics of the wheat flour (Brazil, 2010), the wheat

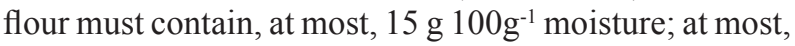

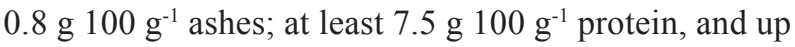
to $100 \mathrm{mg} \mathrm{KOH} 100 \mathrm{~g} \mathrm{~g}^{-1}$ fat acidity, to be rated as type

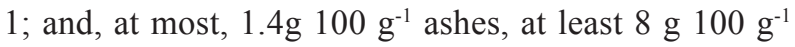
protein and $100 \mathrm{mg} \mathrm{KOH} 100 \mathrm{~g}^{-1}$, to be considered type 2. Considering current legislation, all the obtained flours were rated as type 1 wheat flour.

The wheat flours presented low ashes content, favoring the quality of final products. The content varied 


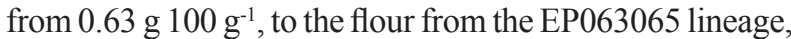

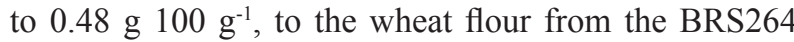
cultivar, estimated in whole matter. High amounts of ashes content can darken the core and the crust, which is an undesirable factor in some bread products, making the control of this parameter a necessity. In products such as cookies and cakes, high amounts of ashes content do not interfere in the quality of the final product, even being an ally in regards of nutritional quality. This way, the flours from the evaluated lineages present great potential, regarding their application in bread production.

All the flours from the lineages were considered equal to the flour from the CD108 cultivar, in regards of the ashes content. The wheat flour from the EP063065 lineage was the only, among the others, that differed from the BRS264 cultivar $(\mathrm{p}<0.05)$. Camargo and Camargo (1987), while determining the mineral material content in new wheat lineages, found results similar to the ones

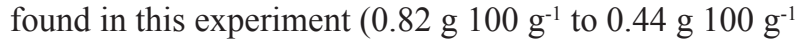
MS). The mineral matter is considered an indicative of the bran amount incorporated to the flour, or, its extraction degree, since these minerals come mainly from the pericarp (Cauvain; Young, 2009).

According to Dendy and Dobraszczyk (2003) and Germani (2003), the protein content for fermented products is usually considered to have ideal protein in

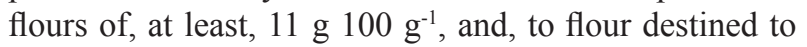
the production of cookies and cakes, an average amount

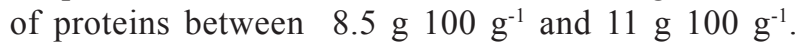
This way, the wheat flours evaluated do not present the protein content adequate to being used in the fabrication of fermented products, because the protein amounts vary

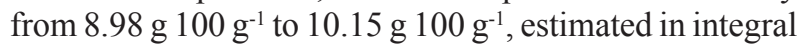
matter. All the flours from the lineages were considered equal to the one from the BRS264 cultivar. Only the flour from the EP066066 lineage was considered to have a lower protein content, when compared to the flour obtained from the cultivar CD108. Camargo and Camargo (1987) and Gutkoski et al. (2007a) found higher results (12 g $100 \mathrm{~g}^{-1}$

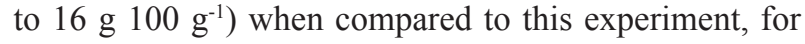
crude protein.

Considering the content found and the tolerated range by the legislation $\left(100 \mathrm{mg}^{100 \mathrm{~g}^{-1}}\right)$, it can be said that the wheat flours presented low acidity. The wheat flour from the EP062043 lineage was the only that had similar values to the ones of the flours from the two cultivars. Gutkoski et al. (2007b), evaluating the characteristics of wheat flour enriched with iron and folic acid, during the storage and verifying its influence in the production of sliced bread, found that the wheat flour had initial fat acidity of $19.90 \mathrm{mg} \mathrm{KOH} 100 \mathrm{~g}^{-1}$, which is a value close to the one found in this experiment.

The results obtained during the evaluation of the flour color are presented in Table 2. The flour $\mathrm{L}^{*}$ is affected by the bran content or foreign materials, while the yellow intensity is related to the amount of pigments found in the wheat (Gutkoski; Durigon; Mazzutti, 2008). The flour luminosity varied from 92.66 to 95.76 . Only the flours of the EP063065 and EP064021 lineages were considered equal to the flour from the CD108 cultivar. It is important to highlight that all the flours from the evaluated lineages presented high luminosity, even considering that the wheat milling was done at an experimental mill, with average extraction of $75 \%$. In relation to the $\mathrm{a}^{*}$ parameter, the wheat flours of the EP063065, EP064021 and EP062043 lineages were considered equal to the flour from the BRS264 and only the flours from the last two were equal to the one from the CD108 cultivar.

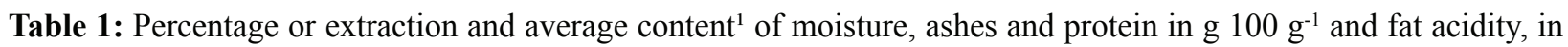
$\mathrm{mg} \mathrm{KOH} 100 \mathrm{~g}^{-1}$ whole matter of the studied wheat flours.

\begin{tabular}{cccccc}
\hline \multirow{2}{*}{ Treatment } & \multirow{2}{*}{ Extraction } & Moisture* & Ashes* & Protein* & Fat acidity** \\
\cline { 4 - 5 } & & & & Average $^{*}$ & \\
\hline EP066066 & 76 & 14.2 & $0.52 \mathrm{ab}$ & $8.98 \mathrm{~b}$ & $14.78 \mathrm{a}$ \\
EP066055 & 73 & 12.7 & $0.53 \mathrm{ab}$ & $9.97 \mathrm{a}$ & $14.69 \mathrm{a}$ \\
EP064021 & 74 & 13.0 & $0.56 \mathrm{ab}$ & $10.15 \mathrm{a}$ & $18.30 \mathrm{~b}$ \\
EP062043 & 75 & 14.2 & $0.55 \mathrm{ab}$ & $9.55 \mathrm{ab}$ & $16.13 \mathrm{ab}$ \\
EP063065 & 75 & 13.8 & $0.63 \mathrm{~b}$ & $9.63 \mathrm{ab}$ & $14.59 \mathrm{a}$ \\
CD108 & 76 & 13.8 & $0.55 \mathrm{ab}$ & $9.84 \mathrm{a}$ & $18.70 \mathrm{~b}$ \\
BRS264 & 76 & 14.1 & $0.48 \mathrm{a}$ & $9.60 \mathrm{ab}$ & $14.23 \mathrm{a}$ \\
\hline
\end{tabular}

${ }^{1}$ Average of three replicates. ${ }^{2}$ Averages followed the same letter in the column must be considered equal, according to the Tukey test $(\mathrm{p}<0.05) .{ }^{*} \mathrm{~g} 100 \mathrm{~g}^{-1} \cdot * * \mathrm{mg} \mathrm{KOH} 100 \mathrm{~g}^{-1}$. 
Table 2: Average values ${ }^{1}$ of the $L^{*}$ (luminosity) and $a^{*}$ and $b^{*}$ parameters of the wheat flour color.

\begin{tabular}{clcccc}
\hline \multirow{2}{*}{ Treatment } & \multicolumn{1}{c}{$\mathrm{L}^{*}$} & $\mathrm{a}^{*}$ & $\mathrm{~b}^{*}$ & \multicolumn{1}{c}{$\Delta \mathrm{L}$} & $\Delta \mathrm{L}$ \\
\cline { 2 - 5 } & & Average $^{2}$ & & CD108 & BRS264 \\
\hline EP066066 & $95.66 \mathrm{a}$ & $-0.15 \mathrm{~cd}$ & $7.77 \mathrm{a}$ & 0.64 & 3.00 \\
EP066055 & $94.21 \mathrm{c}$ & $0.05 \mathrm{~d}$ & $8.33 \mathrm{~b}$ & -0.82 & 1.55 \\
EP064021 & $95.44 \mathrm{ab}$ & $-0.63 \mathrm{ab}$ & $10.01 \mathrm{~d}$ & 0.41 & 2.78 \\
EP062043 & $95.76 \mathrm{a}$ & $-0.64 \mathrm{ab}$ & $9.75 \mathrm{~d}$ & 0.73 & 3.09 \\
EP063065 & $95.37 \mathrm{ab}$ & $-0.28 \mathrm{bc}$ & $9.20 \mathrm{c}$ & 0.35 & 2.71 \\
CD108 & $95.03 \mathrm{~b}$ & $-0.82 \mathrm{a}$ & $10.91 \mathrm{e}$ & - & - \\
BRS264 & $92.66 \mathrm{~d}$ & $-0.52 \mathrm{ab}$ & $8.90 \mathrm{c}$ & - & - \\
\hline
\end{tabular}

${ }^{1}$ Average of three replicates. ${ }^{2}$ Averages followed by the same letter in the column must be considered equal, at $5 \%$ of probability.

Regarding the yellow intensity $\left(b^{*}\right)$, the wheat flours from the EP064021 lineage, as well as the flour from the CD 108 cultivar, obtained greater highlight, being different from each other. However, the flours from the wheats EP066066 and EP066055 presented the lowest yellow intensity, being considered different from each other and from the cultivars. Only the flour from the EP063065 lineage was considered equal to the flour from the BRS264 cultivar, in this parameter. All the wheat flour lineages that were evaluated, except for the EP066055 lineage, were shown to be lighter than the flours from the two cultivars.

The results found for the rheological evaluations are described in Tables 3 and 4. Montenegro e Ormenese (2005) rated the quality of flour evaluating the gluten index (GI), in which the flour is considered: very good, with GI higher than $90 \%$, good, with GI between $60 \%$ and $90 \%$, average, with GI between $40 \%$ and $60 \%$, and weak, with GI lower than $40 \%$. Considering this classification, the flours would form the following groups: EP064021, EP062043, EP063065 and CD108, rated as very good, and the others, as good flour. No meaningful divergence was identified among the flours in relation to the GI. When the dry gluten percentage is observed, it is noted that the values are not discrepant among the treatments, also not identifying meaningful difference among the flours from the lineages in relation to the flours from the cultivars. No difference was identified among the flours of the lineages and the cultivars, however, Felicio et al. (1996) consider wheats that produce values higher than 30\% GU as being of high quality.

Guarienti (1996) and Montenegro and Ormenese (2005) consider a falling number (FN) lower than 150 seconds, as coming from wheats of high $\alpha$-amylase activity; wheat with FN between 200 and 300 seconds, as being great for bakery, and wheats with FN above 30 seconds, as with low diastatic activity, requiring the addition of an enzyme to improve or maintain the quality of the product in which it is employed. FN above 400 seconds considers that the wheat has no diastatic activity. Considering things, all the wheat flours presented low $\alpha$-amylase activity, with $\mathrm{FN}$ varying from 309 seconds (CD108) and 365 seconds (EP064021), factor that can be easily corrected with the addiction of the $\alpha$-amylase during the process of flour fabrication at the milling industry. It is important to point out that it is easier to control wheats with low diastatic activity than wheats with high activity (Felício et al., 1996).

The flours from the EP062043 and EP063065 lineages were the only ones considered to have $\mathrm{FN}$ with no meaningful difference from the CD108 cultivar $(p<0.05)$. Costa et al. (2008) found FN near to the values found in this experiment in imported wheats and wheat flours; however, the national wheats evaluated by the authors presented FN between 231 and 279 seconds. Felício et al. (1996) and Gutkoski et al. (2007a), found, in their experiments with wheat cultivated in the cerrado, FN beyond 310 seconds, as observed in this study.

Considering the alveographic parameters, the wheat flour from the EP064021 lineage was revealed to be the most elastic, significantly different from the others, and the flour from the EP062043 lineage, the only different from the flour from the BRS264 cultivar, the most extensible. Still observing the alveographic data, it is noted that the wheat flours showed to be very balanced in regards of the $\mathrm{P} / \mathrm{L}$ relation, in which lineage EP064021 was the only one to be different from the flour from the standard cultivars. The flours from wheats EP063065, EP066066, EP062043 and EP066055, in relation lower than 1, are equal to the flour from the CD108 wheat cultivar. In a study about wheat cultivated in the countryside of the state of São Paulo, the $\mathrm{P} / \mathrm{L}$ relation was revealed to be lower than 1 to fifteen out of sixteen studied samples (Felício et al., 1996). 
Table 3: Average values ${ }^{2}$ of gluten index, dry gluten, humid gluten, elasticity, extensibility, gluten strength and falling number of the tested wheat flours.

\begin{tabular}{ccccccccc}
\hline \multirow{2}{*}{ Treatment } & $\%$ GI & $\%$ GS & $\%$ GU & FN (seg.) & P $(\mathrm{mm})$ & L $(\mathrm{mm})$ & P/L & W $\left(10^{-4} \mathrm{~J}\right)$ \\
\cline { 2 - 8 } & \multicolumn{7}{c}{ Average $^{1}$} \\
\hline EP066066 & $86.71 \mathrm{a}$ & $32.85 \mathrm{~b}$ & $25.56 \mathrm{a}$ & $319 \mathrm{~b}$ & $52 \mathrm{a}$ & $102 \mathrm{ab}$ & $0.47 \mathrm{a}$ & 145.0 \\
EP066055 & $88.60 \mathrm{a}$ & $36.85 \mathrm{a}$ & $31.27 \mathrm{a}$ & $326 \mathrm{c}$ & $78 \mathrm{~cd}$ & $93 \mathrm{ab}$ & $0.78 \mathrm{abc}$ & 244.2 \\
EP064021 & $88.44 \mathrm{a}$ & $34.02 \mathrm{ab}$ & $28.94 \mathrm{a}$ & $365 \mathrm{e}$ & $106 \mathrm{f}$ & $89 \mathrm{ab}$ & $1.10 \mathrm{c}$ & 253.9 \\
EP062043 & $98.25 \mathrm{a}$ & $35.39 \mathrm{ab}$ & $27.30 \mathrm{a}$ & $324 \mathrm{ab}$ & $74 \mathrm{bc}$ & $79 \mathrm{a}$ & $0.88 \mathrm{bc}$ & 273.8 \\
EP063065 & $92.00 \mathrm{a}$ & $33.98 \mathrm{ab}$ & $28.80 \mathrm{a}$ & $324 \mathrm{ab}$ & $88 \mathrm{e}$ & $104 \mathrm{ab}$ & $0.78 \mathrm{abc}$ & 304.0 \\
CD108 & $92.60 \mathrm{a}$ & $35.67 \mathrm{ab}$ & $28.93 \mathrm{a}$ & $309 \mathrm{a}$ & $85 \mathrm{de}$ & $113 \mathrm{ab}$ & $0.69 \mathrm{ab}$ & 321.1 \\
BRS264 & $85.84 \mathrm{a}$ & $34.21 \mathrm{ab}$ & $29.78 \mathrm{a}$ & $338 \mathrm{~d}$ & $67 \mathrm{~b}$ & $119 \mathrm{~b}$ & $0.53 \mathrm{a}$ & 288.5 \\
\hline
\end{tabular}

GI (gluten index); GS (dry gluten); GU (humid gluten); P (elasticity); L (extensibility); W (gluten strength); FN (Falling Number). ${ }^{1}$ Averages followed by the same letter in the column must be considered equal, with $5 \%$ of probability. ${ }^{2}$ Average of three replicates.

Table 4: Average farinographic results ${ }^{1}$ for the evaluated wheat flours.

\begin{tabular}{ccccc}
\hline Treatment & Absorption & $\mathrm{TC}^{*}$ & $\mathrm{TD}^{*}$ & $\mathrm{E}^{*}$ \\
\hline EP066066 & 62.9 & 1.8 & 2.3 & 1.8 \\
EP066055 & 65.6 & 2.3 & 3.3 & 1.5 \\
EP065021 & 71.1 & 2.3 & 2.8 & 1.0 \\
EP062043 & 62.2 & 3.5 & 5.0 & 4.0 \\
EP063065 & 67.5 & 3.2 & 4.5 & 3.0 \\
CD108 & 65.5 & 3.0 & 4.0 & 3.0 \\
BRS264 & 59.7 & 2.2 & 3.8 & 2.8 \\
\hline
\end{tabular}

Absorption expressed in percentage (\%). *TC [arrival time (min.)]; TD [development time (min.)]; E [stability (min.)]. ${ }^{1}$ Average of three replicates.

Willians et al. (1988) consider as ideal flour for bread those which have P/L between 0.5 and 1.2 , which corresponds to the characteristic of all the flours from the evaluated wheat lineages. When considering gluten strength (W), the same authors consider as very strong the ones with $\mathrm{W}$ over 401 ; strong, between 301 and 400; medium strong, between 201 and 300; medium, between 101 and 200; weak, from 51 to 100; and very weak, below 50 . Considering this ratings, the wheat flours with strong gluten were the ones from the EP063065 and the CD108 grains, and as medium gluten the flour from the EP066066 lineage. The other wheat flours were considered medium strong. Considering the $\mathrm{P} / \mathrm{L}$ relation and the $\mathrm{W}$, it can be said that all of the wheat flours presented characteristics that are adequate to bread fabrication; however, the wheat flour obtained from the EP066066 lineage would be more adequate to the fabrication of cakes and cookies.

The water absorption of the flours varied from $71.1 \%$ to $59,7 \%$. Ideal absorption is considered to be from $50 \%$ to $54 \%$, to flours destined to the fabrication of cookies, and from $60 \%$ to $62 \%$ for standard flours for bakery (Cauvain; Young, 2009). Considering this statement, the flours from the EP062043 and EP066066 lineages would be considered adequate for bakery, as well as the BRS264 cultivar. The other flours presented absorption higher than $65 \%$, absorption also found in the flour from the CD108, being considered inappropriate for bakery. Camargo and Camargo (1987), Faroni et al. (2002) and Germani (2003) point out that high water absorption, from a practical point of view, represents higher production profit. The percentage of water absorption is influenced by factors such as moisture, protein content, starch damage level, and hemicellulose content (Camargo; Camargo, 1987).

The tested flours had an arrival time that ranged from 3.5 minutes and 1.8 minutes. The flours from the EP066055 and EP065021 lineages had the same arrival time as that found for the flour from BRS264 wheat. The flours of the EP063065 and EP062043 lineages had the highest times of arrival, as well as the flour from the CD108 cultivar. In the determination of the technological characteristics of wheats cultivated in the cerrado, Gutkoski et al. (2007a) found arrival times which vary from 1.3 to 22 minutes, being that most of the cultivars had values above 9 minutes. Lower arrival times mean lower energy expenditure at a bakery, 
because the mixing time will be lower, thus consuming less energy.

The development time is directly related to the flour's baking capacity, in which a flour of good baking capacity produces a tracing that reaches maximum consistency more slowly, and is usually much more stable (Faroni et al., 2002; Dendy; Dobraszczyk, 2003). Considering this statement made by the authors, the flours from the EP062043 and EP063065 wheats presented higher stability (E) and development time (TD), as well as the flour from the CD108 cultivar. However, the EP066055 and EP065021 wheats presented the lowest $\mathrm{E}$ and TD.

Willians et al. (1988) rate the flours according to their stability, considering as very strong the ones with stability over 15.1 minutes; strong, between 10.1 and 15.0 minutes; medium-strong strength, from 7.1 to 10.0; medium-weak strength, between 4.1 and 7.0 ; weak, between 2.1 and 4; and very weak, below 2.0. Considering the classification suggested by the author, the flours would be placed in the weak (EP062043 and EP063065, which behave like the standards CD108, BRS264) and very weak (EP066066, EP066055 and
EP065021) categories. The mass stability is recognized as an indicative parameter of higher resistance to the kneading and better technological quality (Faroni et al., 2002). The flour stability depends, mainly, on the number of crossed links among the protein molecules present in the gluten, as well as these links' strength (Costa et al., 2008). It means that the flours of the EP062043 and EP063065 lineages probably have the properties cited.

Considering all the farinographic characteristics, it can be said that the flours from the EP062043 and EP063065 lineages stand out, as well as the CD108. However, the EP065021 and EP066066 lineages had the worst performance. This same statement can be said considering the alveographic parameters $\mathrm{P} / \mathrm{L}$ and $\mathrm{W}$, confirming the viscoelastic characteristics of these flours.

On Table 5, there are the parameters used for rating the wheat lineages that were studied. Out of the evaluated wheats, only the grains from the EP066066 lineage were rated as basic wheat. The lineages studied had the same ratings as the cultivars. The CD108 and BRS264 cultivars had the same commercial rating, presented in the $\mathrm{V}$ Reunião da Comissão Brasileira de Pesquisa de Trigo e Triticale (2011).

Table 5: Rating of the wheats according to the Appendix III of the Normative Instruction $n^{\circ} 38$ (Brazil, 2010).

\begin{tabular}{ccccc}
\hline Treatment & FN $($ sec. $)$ & W $\left(10^{-4} \mathrm{~J}\right)$ & Stability $(\mathrm{min})$ & Class \\
\hline EP066066 & 319 & 145 & 1.8 & Basic \\
EP066055 & 325 & 244 & 1.5 & Bread \\
EP064021 & 364 & 254 & 1.0 & Bread \\
EP062043 & 324 & 274 & 4.0 & Bread \\
EP063065 & 323 & 304 & 3.0 & Bread \\
CD108 & 309 & 321 & 3.0 & Bread \\
BRS264 & 337 & 288 & 2.8 & Bread \\
\hline
\end{tabular}




\section{CONCLUSIONS}

In the conditions that this studied happened, lineage EP066066 is rated as basic wheat. The EP066055, EP064021, EP062043 and EP063065 lineages are rated as bread wheat. Among the lineages that were studied, EP062043 stands out, presenting considerable gluten contents, good stability, and good gluten strength, which allows it to be considered identical, or even better, than the BRS264 e CD108 cultivars. New studies can confirm this statement through baking tests.

\section{ACKNOWLEDGMENTS}

The authors thank the FAPEMIG, CAPES, EPAMIG and the Department of Food Science and Department of Agriculture of the Federed University of Lavras.

\section{REFERENCES}

\section{AMERICAN ASSOCIATION OF CEREAL}

CHEMISTIS. Approved methods. 10 ed. Saint Paul, 2000. Available in: $<$ http://methods.aaccnet.org/about. aspx>. Access in: dec. 10, 2013.

\section{ASSOCIATION OF OFFICIAL ANALYTICAL} CHEMISTS. Official methods of analysis of AOAC International. 17 ed. Gaitheersburg, 2000. v. 1, 1094p.

BORGES, J. et al. Use of a global wheat core collection for association analysis of flour and dough quality traits. Journal of Cereal Science, London, 54(1):137-147, 2011.

BRAZIL. Ministério da Agricultura Pecuária e Abastecimento. Instrução Normativa $\mathbf{n}^{\mathbf{0}} \mathbf{3 8}$, of 30 of November, 2010. Regulamento técnico do trigo. Brasília, 2010. Available in: $<$ http:// www.codapar.pr.gov.br/arquivos/File/pdf/ TrigoInstrucaoNormativa3810.pdf $>$. Access in: dec. 10, 2013.

CAMARGO, C. R. D. O.; CAMARGO, C. E. D. O. Trigo: avaliação tecnológica de novas linhagens. Bragantia. 46(2):169-181, 1987.

CAUVAIN, S. P.; YOUNG, L. S. Tecnologia de panificação. Barueri: Manole, 2009. 417p.

COSTA, M. das G. da et al. Qualidade tecnológica de grãos e farinhas de trigo nacionais e importados.
Ciência e Tecnologia de Alimentos. 28(1):220-225, 2008.

DENDY, D. A. V.; DOBRASZCZYK, B. J. Cereales y productos derivados: química y tecnología. Zaragoza: Acribia, 2003. $537 \mathrm{p}$.

FARONI, L. R. D. et al. Qualidade da farinha obtida de grãos de trigo fumigados com dióxido de carbono e fosfina. Revista Brasileira de Engenharia Agrícola e Ambiental. 6(2):354-357, 2002.

FELÍCIO, J. C. et al. Avaliação agronômica e de qualidade tecnológica de genótipos de trigo com irrigação por aspersão no estado de São Paulo. Bragantia. 55(1):147-156,1996.

FRANCO, L. Cerrado brasileiro produz trigo melhor que o da Argentina. 2011. Available in: <http://revistagloborural.globo.com/Revista/ Common/0,,EMI238993-18283,00-CERRADO+B RASILEIRO+PRODUZ+TRIGO+MELHOR+QU $\mathrm{E}+\mathrm{O}+\mathrm{DA}+\mathrm{ARGENTINA} \cdot \mathrm{html}>$.Acess in: mar. 22, 2014.

GERMANI, R. Trigo e farinha de trigo. Rio de Janeiro: CTAA-EMBRAPA, 2003. 109p.

GUARIENTI, E. M. Qualidade industrial de trigo. 2. ed. Passo Fundo: EMBRAPA Trigo, 1996. 36p.

GUARIENTI, E. M. et al. Qualidade de trigo: aspectos tecnológicos e sanitários. Informe Agropecuário, Belo Horizonte, 34(274):72-82, 2013.

GUTKOSKI, L. C.; DURIGON, A.; MAZZUTTI, S. Efeito do período de maturação de grãos nas propriedades físicas e reológicas de trigo. Ciência e Tecnologia de Alimentos. 28(4):888-894, 2008.

GUTKOSKI, L. C. et al. Armazenamento da farinha de trigo enriquecida com ferro e ácido fólico e seu efeito na produção de pão de forma. Alimentos e Nutrição. 18(1):93-100, $2007 \mathrm{a}$.

Características tecnologicas de genótipos de trigo (Triticum aestivum L.) cultivados no cerrado. Ciência e Agrotecnologia. 31(3):786-792, $2007 b$. 
GUTKOSKI, L. C.; JACOBSEN NETO, R.

Procedimento para teste laboratorial de panificação: pão tipo forma. Ciência Rural. 32(5):873-879, 2002.

MONTENEGRO, F. M.; ORMENESE, R. de C. S. C. Avaliação da qualidade tecnológica da farinha de trigo. Campinas: ITAL, 2005. 67p.
REUNIÃO DA COMISSÃO BRASILEIRA DE PESQUISA DE TRIGO E TRITICALE, 5., 2011, Dourados. Informações técnicas para trigo e triticale - safra 2012. Dourados: EMBRAPA Agropecuária Oeste, 2011. 255p. (Sistema de Produção, 9).

WILLIAMS, P. et al. Crop quality evaluation methods and guidelines. 2 ed. Aleppo: ICARDA, 1988. 145 p. 